\title{
A Look At An Implementation Of The Quality Matters Program In A Collegiate Environment: Benefits And Challenges
}

Connie B. Budden, Southeastern Louisiana University, USA

Michael C. Budden, Southeastern Louisiana University, USA

\begin{abstract}
As traditional universities grapple with an onslaught of demand for distance education a recurring call to ensure quality in such offerings arises. The Quality Matters Program intends to guarantee such quality through a peer-centered process and offers a certification process to help assure quality in online and blended courses. This report is a preliminary look at perceived benefits and challenges that implementing the process entails.
\end{abstract}

Keywords: Quality Matters Program; Online Education; Benefits; Challenges; Certification

\section{INTRODUCTION}

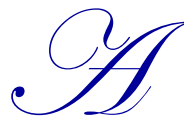

ccording to the SREB (2006) the rapid growth of online learning in the past 10 years has focused increasing attention on what constitutes a quality online course. Major improvements have taken place in the technology used to access and provide online courses. Also, an improved understanding by educators of today's technology savvy students allows educators to better serve the needs of today's students.

Online learning began in the 1990s and the increased access to innovative technology and the use of new pedagogy have broadened individuals' access to higher education. Many colleges and universities were concerned and remain concerned about the issue of assuring the delivery of quality online educational programs. This concern is central to discussions of online-delivery, as educators have long recognized that assessing good teaching in a classroom environment is not an easy task. Compared to face-to-face delivery assessments, assessing online offerings presents new and potentially increased difficulties to any assessment process and complicates efforts to assure quality. Quality issues are often included in discussions on teaching effectiveness, faculty-to-student ratios, attrition rates, and student satisfaction (Chao, Saj, Tessier 2006).

According to the Quality Matters Program website, QM is "a faculty-centered, peer review process that is designed to certify the quality of online and blended courses (www.qualitymatters.org)." The program is a leader in the assurance of quality in the design of online courses. The quality matters program is made up of three components: the QM rubric, the peer review process and QM professional development.

Southeastern Louisiana University, in an effort to improve and ensure the quality of online classes taught at Southeastern has encouraged faculty to complete the online QM course conveniently located on its Blackboard website. Southeastern has approximately 709 faculty members, of which 86 have achieved Quality Matters certification. The College of Business has approximately 50 faculty members, 10 of which are QM certified.

\section{SOUTHEASTERN LOUISIANA UNIVERSITY'S QUALITY MATTERS WEBSITE COURSE OVERVIEW}

The university's Blackboard site has a section available to faculty wishing to pursue QM certification. The website was designed to provide faculty members with current information and exercises designed to acquaint users 
with QM. The site mentions that Quality Matters is a collegial review process where reviewers provide feedback on the course design in two ways: (1) the awarding of points for specific review standards, and (2) providing substantial, constructive, and specific comments and suggestions with regard to both areas for improvement and existing strengths.

The reviewer is asked to take the student's perspective with regard to clarity and organization in addressing the assessments of learning relative to QM. The Quality Matters rubric and review processes are dynamic and reflect national standards of best practice and the research literature. This discussion is presented in an easy to use and reference format. to be able to:

Learning Objectives for pursuing QM certification are presented. Certified faculty members are expected

- Describe the critical materials, processes, and administrative elements of the Quality Matters online course quality assurance program

- $\quad$ Apply the Peer Course Review rubric and scoring system to online or hybrid courses

- Write useful recommendations for course development, modification and/or enhancement

The material is presented in four basic learning units. Unit 1 describes QM and its philosophy. Learning unit 2 discusses designing a quality online experience. Learning unit 3 presents $\mathrm{QM}$ rubric and standards and the standards quiz. The fourth unit discusses the concept of a team and review process (including a quiz). At the completion of the four primary units a final evaluation and quiz is presented to check understanding of the process. A faculty member is admonished that all activities must be completed and that an overall score of 85 is necessary to successfully complete the course.

\section{PRELIMINARY INVESTIGATION}

As a prelude to an intended campus-wide survey, informal discussions with certified faculty were initiated. Thus, 7 College of Business faculty members who had become certified provided their thoughts with regard to the process and its impact on their teaching. Faculty relayed a variety of thoughts, pro and con relative to their efforts and classification as QM certified. Among the topics deemed relevant were:

- Whether QM certification had been beneficial to your classes?

- How had QM certification improved online or partially online classes?

- Would certified faculty members encourage fellow faculty members to get certification?

- What was the most difficult part of getting certified?

- The number of hours spent QM training and certification?

- Whether and how should the University/College encourage additional faculty members to seek certification?

Seven business faculty involved in this discussion addressed these issues. Faculty had a range of opinions concerning the usefulness of QM in their efforts. Some felt certification should be encouraged and rewarded. Others felt it was less helpful and beneficial in the development of their online classes. These tables contain some of the benefits, challenges and recommendations as mentioned in this preliminary discussion.

QM Certification Was Seen As Having (Benefits)

\begin{tabular}{|l|}
\hline Added information to online classes concerning technical support available to students \\
\hline Added information to online class concerning appropriate online behaviors \\
\hline Provides minimal guidelines for the construction of online classes to assure quality \\
\hline Impacted materials included in classes \\
\hline Helped improve the structure of the online class \\
\hline Provided students a stable and consistent interface among all course offerings \\
\hline Helped make information concerning online classes more visible \\
\hline Helped faculty to focus on material to be covered over the entire semester \\
\hline
\end{tabular}


Challenges of QM Certification (Some Felt That Certification Had...)

\begin{tabular}{|l|}
\hline Not improved the instruction quality in their classes \\
\hline The training didn't use business examples so relevance was questioned \\
\hline The training program had been time consuming \\
\hline Instructions that were not clear \\
\hline The local implementation was perceived by one as having not been 100\% inline with the national QM guidelines \\
\hline Not encouraged by some administrators \\
\hline Presented obstacles that some faculty would not adapt or readily adopt \\
\hline Removed some creativity from class \\
\hline
\end{tabular}

Overall most faculty members felt there had been a need at Southeastern for some type of training program and standards for online classes. The most often stated complaint about the QM training course was the amount of time involved in completing the course for certification.

In an effort to improve the quality of online classes at Southeastern the faculty put forth a number of recommendations.

\begin{tabular}{|l|}
$\qquad$ Recommendations for QM Included \\
\hline Encourage faculty certification with rewards \\
\hline Require faculty teaching 100\% or 50\% online classes to obtain QM certification \\
\hline The use of examples from all disciplines \\
\hline Providing additional examples of how standards can be applied to different courses \\
\hline Encouraging all administrators to consider QM certification a strong faculty development activity \\
\hline Encouraging administrators to consider QM a good service activity \\
\hline $\begin{array}{l}\text { Encourage certification with non-financial rewards: such as release time, dedicated parking spot, assignment of a GA to help } \\
\text { develop classes, etc. }\end{array}$ \\
\hline Provide funds to purchase/lease equipment to enhance the learning environment \\
\hline
\end{tabular}

There were different training programs for QM certification offered to faculty members. The first original training program on campus involved a two-day workshop and some online training. The second and subsequent training on the QM process/certification method was offered completely online and in a virtual format allowing faculty to access the material at any time of day.

Faculty Time Spent on Certification According To Those in the Discussion

\begin{tabular}{|l|l|}
\hline \multicolumn{1}{|c|}{ Workshop Certification: } & \multicolumn{1}{|c|}{ Online Certification: } \\
\hline 2 days (approximately 8 hours) & Forty-eight hours \\
\hline 2 days (approximately 6 hours) & 2 days (10 hours) \\
\hline 2 days (not sure) & 2 days (12 hours) \\
\hline & Not sure \\
\hline
\end{tabular}

Online class presence in the learning environment is no longer a question. Such classes are part of the norm and will only make further inroads into academe. Universities should strive to find convenient and helpful programs to ensure quality and consistency among online offerings. The important role that quality and consistency plays in the learning environment cannot be over emphasized. Certification and adherence to standards should be encouraged and rewarded.

This was a preliminary study of the perceptions of some of the faculty who have achieved QM certification. A larger study across campus is being planned in order to determine if these findings can be generalized across campus. This preliminary look will be used to develop a questionnaire to assess campus-wide knowledge and satisfaction with the program. Its impact on our students needs to be assessed as well. 


\section{AUTHOR INFORMATION}

Connie B. Budden is an instructor of Management at Southeastern Louisiana University, USA. Her research interests include business education, global business, human resource management issues and business sustainability. E-mail: cbudden@selu.edu (Corresponding author)

Michael Craig Budden, Ph.D., is the Candies Professor of Marketing at Southeastern Louisiana University, USA. His research interests include commercial law, ethics, retail control, and business education. E-mail: mbudden@selu.edu

\section{REFERENCES}

1. Chao, Tracy, Saj, Tami. Tessier, Felicity (2006). Establishing a Quality Review, www.educause.edu

2. www.qualitymatters.org

3. Southern Regional Education Board, Standards for Quality Online Courses, Nov. 2006, www.sreb.edu 